Article

\title{
Talking Big: Lessons Learned from a 9000 Hectare Restoration in the Northern Tallgrass Prairie
}

\author{
Philip J. Gerla ${ }^{1, *}$, Meredith W. Cornett ${ }^{2}$, Jason D. Ekstein ${ }^{3}$ and Marissa A. Ahlering ${ }^{4}$ \\ 1 The Nature Conservancy and University of North Dakota, 81 Cornell Street Stop 8358, \\ Grand Forks, ND 58202, USA \\ 2 The Nature Conservancy, 394 Lake Avenue S., Suite 308, Duluth, MN 55802, USA; \\ E-Mail: mcornett@tnc.org \\ 3 Minnesota Department of Natural Resources, 31077 State Hwy 32 S., Mentor, MN 56736, USA; \\ E-Mail: jason.ekstein@state.mn.us \\ 4 The Nature Conservancy, 414 E. Clark Street, Vermillion, SD 57069, USA; \\ E-Mail: mahlering@tnc.org \\ * Author to whom correspondence should be addressed; E-Mail: pgerla@tnc.org; \\ Tel.: +1-701-777-3305; Fax: +1-701-777-4449.
}

Received: 28 August 2012; in revised form: 6 November 2012 / Accepted: 6 November 2012 /

Published: 13 November 2012

\begin{abstract}
Large tracts ( $>1000 \mathrm{ha}$ ) of prairie are essential to the sustainability of grassland ecosystem services, yet in many ecoregions only small fragments remain. Glacial Ridge is among the largest prairie-wetland restorations ever attempted. Started in 2000, the 9000 ha project in northwest Minnesota, USA, was initiated to reconnect 14 small tallgrass prairie remnants. In all, 15,200 ha of contiguous habitat comprise the project's direct accomplishment. We created a partnership of more than 30 organizations, filled $177 \mathrm{~km}$ of drainage ditch, restored 1240 ha of wetland, and replanted 8100 ha. Flooding has been mitigated, water quality improved, and native vegetation reestablished. Animals not documented for decades have again occupied the site. Despite these accomplishments, the project would have been unnecessary if the land had been purchased in the 1970s, prior to conversion to agriculture, at one-tenth the restoration cost. Our challenges related to funding, differences in partners' restoration philosophy, community concerns about floods and tax losses, difficulties in obtaining seed, and follow-up management of invasive weeds. We summarize the restoration process and share basic principles that will help others to develop large-scale prairie restoration projects in the future.
\end{abstract}


Keywords: grassland; land-use management; conservation; landscape ecology; restoration; prairie

\section{Introduction}

Because of its high agricultural productivity and vulnerability to conversion, temperate grassland is considered the most fragmented, altered, and threatened of terrestrial biomes [1,2]. Recent studies have demonstrated the importance of perennial grassland to the sustainability of soil food-web complexity and stability, regional resilience to climate change, storage of soil carbon, and mitigation of nitrate transport into streams and rivers [3-5]. In North America's northern tallgrass ecoregion, less than 2.5\% of native prairie remains [6]. Furthermore, most remnants are small and shown to be diminishing in size and quality [7].

The call for large-scale restoration to reconnect fragmented ecosystems in a variety of biomes, including grasslands, is gaining traction within the conservation community [7-9]. Moreover, the deliberate act of restoration strives to enhance not only its overall health and integrity, but also its long-term sustainability [10].

In our context, "large-scale" means 1000 s to 100,000 s of hectares [9], or an area sufficiently large to encompass and restore the natural heterogeneity of the landscape [11]. Restorations of this scale are uncommon, however, and standard methodologies and best practices for restoring large areas have yet to be developed [12]. Additionally, large-scale restorations confront social, financial, and logistical challenges. For example, local political leaders and property owners often oppose conservation projects on the grounds that they will fail to provide tax revenue and reduce direct economic benefits to the community [13]. Paying for the restoration across such a large area, in addition to the expense of purchasing the land, may seem an insurmountable hurdle. Logistically, seed availability, especially local ecotypes with sufficient species diversity (e.g., [14-17]), poses challenges because so little tallgrass prairie remains. Where sufficient seed is available, it is expensive. Despite these challenges, success in re-establishing large tracts of tallgrass prairie carries important benefits for society and nature, both in terms of sustaining vital services (e.g., improving water quality) [18] and in many cases contributing directly to regional economies [19].

To date, most extensive tallgrass prairie restoration projects in North America have aimed to recover lost habitat and reconnect native remnants (Table 1). Starting conditions range from non-native pasture with a few scattered prairie remnants (e.g., Midewin National Tallgrass Prairie) to vast areas of row-cropped agriculture. Covering 9000 contiguous hectares, the Glacial Ridge Project in Minnesota, USA is the largest temperate-tallgrass prairie restoration to date (Table 1). Henceforth, we use the definition of restoration endorsed by the Society for Ecological Restoration: “...the process of assisting the recovery of an ecosystem that has been degraded, damaged, or destroyed" [10]. In this project specifically, the goal was to recover the tallgrass prairie from a relatively recent history of row-crop agriculture and gravel mining. 
Table 1. Features of the large ( $>1000$ ha) northern tallgrass prairie — wetland preserves and restorations.

\begin{tabular}{|c|c|c|c|c|c|c|c|c|}
\hline \multirow[b]{2}{*}{ Name } & \multirow[b]{2}{*}{ State } & \multirow[b]{2}{*}{$\begin{array}{c}\text { Initial } \\
\text { Year }\end{array}$} & \multirow[b]{2}{*}{ Lead Agencies } & \multicolumn{4}{|c|}{ Restored Area (ha) } & \multirow[b]{2}{*}{$\begin{array}{c}\text { Primary } \\
\text { Purposes }^{2}\end{array}$} \\
\hline & & & & Total & Completed & Planned & Other $^{1}$ & \\
\hline Glacial Ridge & Minnesota & 2000 & $\begin{array}{l}\text { The Nature Conservancy/ } \\
\text { U.S. Fish and Wildlife Service }\end{array}$ & 9000 & 8100 & 0 & 900 & $a, b, f$ \\
\hline $\begin{array}{l}\text { Midewin National } \\
\text { Tallgrass Prairie }\end{array}$ & Illinois & 2002 & U.S. Fish and Wildlife Service & 7380 & 600 & 470 & 6310 & $\mathrm{a}, \mathrm{d}, \mathrm{g}$ \\
\hline Kankakee Sands & Indiana & 1997 & $\begin{array}{c}\text { The Nature Conservancy/ } \\
\text { Efroymson Family }\end{array}$ & 3320 & 2430 & 320 & 570 & $\mathrm{a}, \mathrm{d}, \mathrm{f}$ \\
\hline $\begin{array}{l}\text { Emiquon Preserve } \\
\text { and NWR } \\
\end{array}$ & Illinois & 2007 & $\begin{array}{l}\text { The Nature Conservancy/ } \\
\text { U.S. Fish and Wildlife Service }\end{array}$ & 3200 & 2990 & 170 & 40 & $\mathrm{a}, \mathrm{c}, \mathrm{e}, \mathrm{f}$ \\
\hline Neal Smith NWR & Iowa & 1992 & U.S. Fish and Wildlife Service & 2260 & 1380 & 880 & 0 & $\mathrm{a}, \mathrm{e}, \mathrm{f}$ \\
\hline Platte River Prairies & Nebraska & 1994 & The Nature Conservancy & 2020 & 610 & 80 & 1330 & $\mathrm{a}, \mathrm{e}, \mathrm{f}$ \\
\hline Nachusa Grasslands & Illinois & 1986 & The Nature Conservancy & 1250 & 1010 & 240 & 0 & $\mathrm{a}, \mathrm{d}, \mathrm{f}$ \\
\hline \multicolumn{9}{|c|}{1 Prior and/or existing grassland, pasture, woodland, leased land, developed, or otherwise unrestored tracts } \\
\hline \multicolumn{9}{|l|}{${ }^{2}$ Primary purposes } \\
\hline \multicolumn{9}{|c|}{ a-enhance existing natural habitat } \\
\hline \multicolumn{9}{|c|}{$\mathrm{b}$-improve or protect water quality } \\
\hline \multicolumn{9}{|c|}{$\mathrm{c}$ - mitigate flood damage / store water } \\
\hline \multicolumn{9}{|c|}{$\mathrm{d}$ - protect threatened or endangered species } \\
\hline \multicolumn{9}{|c|}{$\mathrm{e}$ - reclaim disturbed / damaged land } \\
\hline \multicolumn{9}{|c|}{$\mathrm{f}-$ reconnect remnant or existing habitat } \\
\hline $\mathrm{g}$-recreation & & & & & & & & \\
\hline NWR—National Wildlife & fuge & & & & & & & \\
\hline
\end{tabular}


When The Nature Conservancy (TNC) purchased Tilden Farms in 2000, wetland drainage, conversion to row crop agriculture, excessive grazing, and aggregate mining had altered more than $90 \%$ of the 9000 ha project area. Most of what makes up the current Glacial Ridge Project was acquired by Texas investors in the early 1970s to form the Crookston Cattle Company. During the 1980 s, the land was sold for $\$ 50$ per acre to investors who created Tilden Farms. By the time TNC purchased the land for $\$ 9,000,000$ in August 2000 , roughly $80 \%$ of the original rangeland had been converted to field and row crop. Agricultural development greatly altered the hydrology of the landscape. To drain Glacial Ridge for large-scale row and field-crop agriculture, several ditches managed and regulated by the county government, along with many private ditches, were maintained or newly excavated during the last few decades. Forty $\mathrm{km}$ of main drainage ditches were established as early as the 1920s and a more extensive $(150 \mathrm{~km})$ network of small, private ditches was created with the start of wheat and soybean production in the early 1980s. Sand and gravel extraction in the area began in the 1960s and expanded rapidly in the 1980s. Prior to TNC's purchase of the property, mineral rights covering the entire 9000 ha were leased to a private company.

The Glacial Ridge Project was initiated in 2000 to reconnect a cluster of 14 fragmented prairie-wetland remnants (totaling $5200 \mathrm{ha}$ ) by restoring the habitat and hydrology of the 9000 ha core area. Restoration of the vegetation and hydrologic function of the prairie wetland complex was completed by 2012 , and contiguous prairie-wetland habitat increased three-fold to roughly 15,200 ha (Figure 1). With the culmination of the 12-year restoration process, our goal is to recount our experience at Glacial Ridge and share what we learned about large-scale restoration. We first portray the Glacial Ridge landscape and the past century of land alterations in northwestern Minnesota, USA. We then describe the overall approach to restoring hydrology and vegetation at a large scale, including enabling conditions and steps involved, and report outcomes to-date, based on the project's original objectives. Finally, we summarize lessons learned during the first 12 years of the project and give our recommendations for optimizing the success for future grassland restoration projects of comparable size and complexity.

\section{Landscape Context and Natural History}

Located in the Northern Tallgrass Prairie Ecoregion [20], Glacial Ridge lies within the 250,000-ha Agassiz Beach Ridges landscape (Figure 1). The landscape straddles the eastern shorelines of glacial Lake Agassiz [21]. Wave action created distinctive beach ridges, exhibiting 3-5 $\mathrm{m}$ of relief and consisting of coarse sandy and gravelly soils, with intervening swales or back-beach areas underlain by wave-washed till and fine sand, silt, and clay deposited in quieter water. Native vegetation on the beach ridges ranges from dry to mesic prairie. Precipitation, local groundwater flow, and evapotranspiration dominate the hydrological processes at the site. Prior to agricultural development, numerous shallow, emergent wetland basins filled the swales separating beach ridges. Zones where groundwater discharges, either ephemerally or throughout the year, are especially important features and give rise to fens and gently sloping wet meadows tightly interwoven with dry gravel prairie (Figure 2). The complex geomorphology necessitated heterogeneous and targeted restoration plans. 
Figure 1. Map of the features and boundaries related to the Glacial Ridge Project. Wellhead protection areas (WHPA) for the city of Crookston, Minnesota, are shown by the dashed outlines. Insert in the lower left shows the location of Glacial Ridge and the maximum extent and upper beach ridges of glacial Lake Agassiz (dotted line).

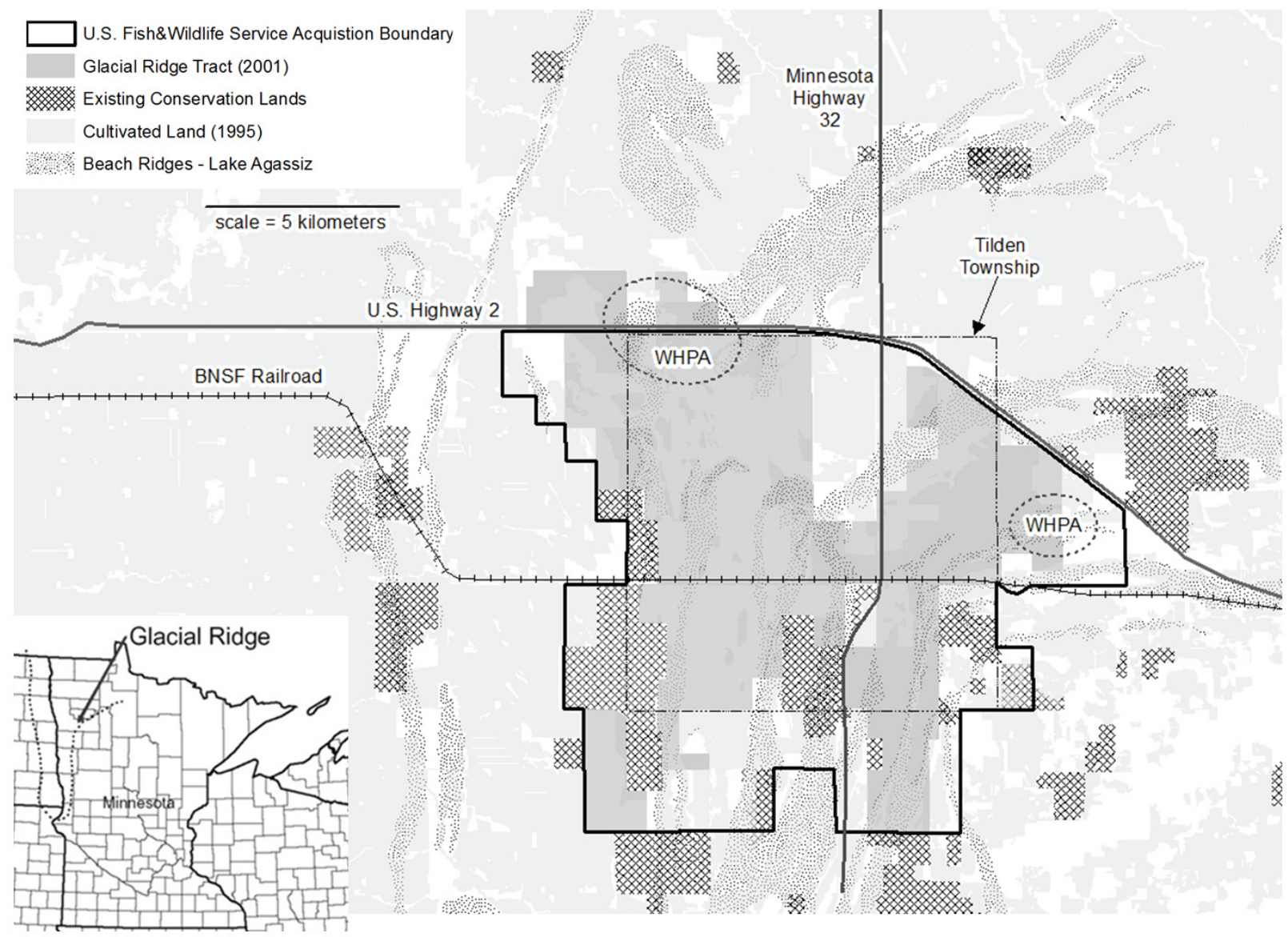

Figure 2. Generalized west to east cross-section (not to scale) through the Glacial Ridge project that shows former beach ridges on glacial Lake Agassiz. Arrows show the deep (dashed) and shallow (solid) groundwater flow system.

W

E

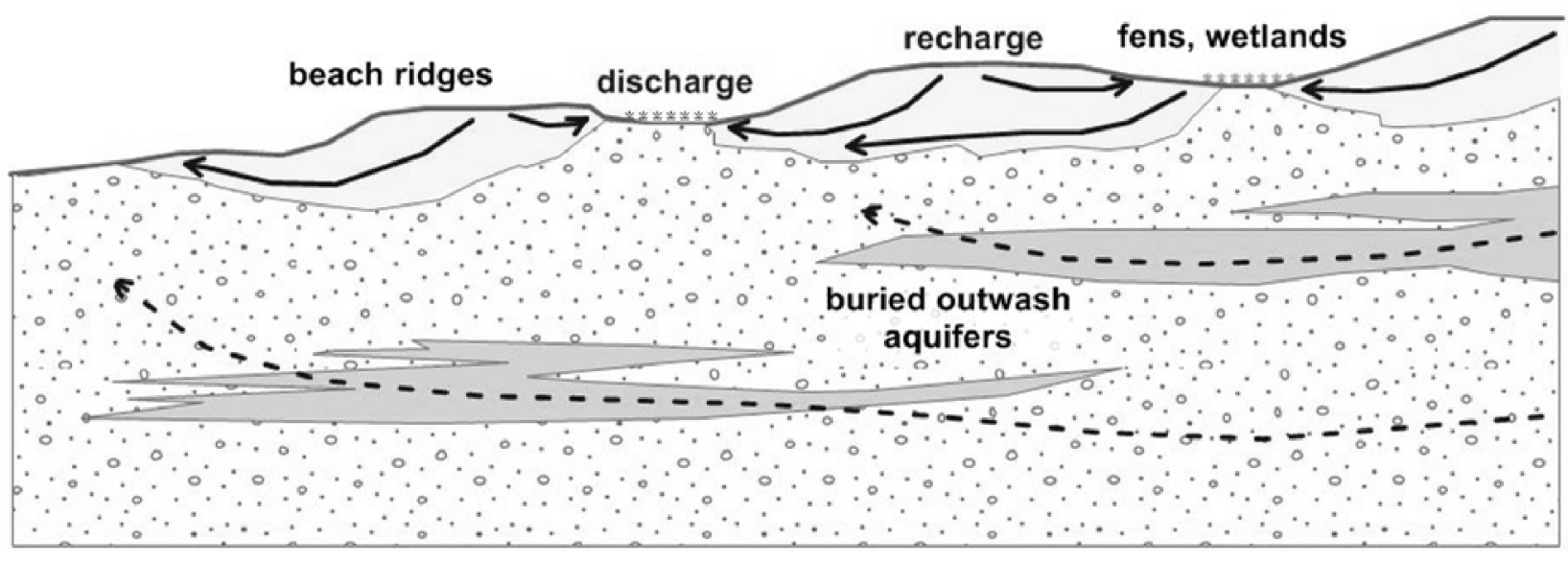


Historical ecological processes at Glacial Ridge were typical of those occurring across the ecoregion and included fire, grazing, and drought [22]. Large fires were a relatively common occurrence in tallgrass prairies [23,24]. However, the landscape and its natural processes have been dramatically altered during the past century, precipitating the need for restoration. Wildfire is suppressed, and prescribed fires occur primarily in the spring [25]. Free-roaming bison were extirpated more than a century ago, vast wet prairies drained, and row-crop agriculture established as the dominant land use. A few remnants of native prairie persist largely because they were too rocky, wet, or otherwise inaccessible for cultivation. Therefore, many prairie obligate species are restricted to the remaining small prairie fragments, and invasive species, such as leafy spurge (Euphorbia esula), Canada thistle (Cirsium arvense), and reed canary grass (Phalaris arundinacea L.) are widespread colonizers of disturbed land.

\section{Restoration}

An overarching goal of our work was to engage local communities in such a way that the project would be valued as a natural asset sustaining important services to residents of northwestern Minnesota. Not broadly considered a traditional restoration goal, the human benefits of restoration projects often go unstated. However, we recognized the potential for mutually supportive social and ecological systems at Glacial Ridge, a project in which sustainability of the ecosystem depended on human intervention [10]. Conversely, the sustainability of communities surrounding Glacial Ridge could be positively affected by a restoration of such ambitious size and scope. More specifically, our restoration goals at Glacial Ridge focused on restoring the landscape's hydrological function, native vegetation, and habitat.

Cultivation of crops in the region depends on effective drainage. Shallow scrapes and surface drains convey excess water off private land and from former wetland basins. Larger ditches, administered and maintained by local government, connect the drainage system for land owners throughout the local watershed. To re-establish natural vegetation and set the trajectory for restoring habitat at Glacial Ridge required removal of the drainage infrastructure developed during the last century.

In conjunction with restoration of hydrology, we established a high-diversity restoration context for nearby fragmented prairie-wetland remnants to reverse habitat loss and associated losses of animal species from the area. Specifically, by reintroducing native plants to the project area, we aimed to lower the threat of invasion by robust non-native plant species (e.g., [26]). Reconnecting remnant habitats was also a critical step in reestablishing gene flow among isolated populations of prairie-obligate species (e.g. butterflies). Also, by expanding existing habitat, we wanted to increase or establish species that require large areas of intact habitat, such as burrowing owl (Athene cunicularia), greater prairie-chicken (Tympanuchus cupido), Wilson's phalarope (Phalaropus tricolor), and marbled godwit (Limosa fedoa). The conservation status of these species in Minnesota [27] is listed either as vulnerable (greater prairie-chicken and marbled godwit) or imperiled (burrowing owl and Wilson's phalarope), generally as a result of habitat loss.

During the restoration process, challenges appeared on several fronts, including public perceptions of drainage in this area of intensive agriculture, the cost and uncertainty of obtaining large quantities of viable, local ecotype seed, and the persistent threat of robust invasive weeds. The following two 
subsections describe in greater detail these specific problems, our approach to their solution, and the outcomes.

\subsection{Drainage and Wetlands}

For field ditches, scrapes, and drains that were entirely on the Glacial Ridge tract, restoration consisted of plugging (installing a clay "stopper" to prevent flow), filling, compacting, and re-grading previously excavated soil to the greatest extent possible. However, more than $50 \mathrm{~km}$ of public ditches were on the Glacial Ridge tract at the start of the project (Figure 3a), and Minnesota state law requires a public hearing and approval by the drainage authority before any changes can be made to the original design and construction of the ditch. Local land owners view effective drainage as essential for crop cultivation, so we needed to assure people early on that hydrological restoration at Glacial Ridge would not affect neighbors' operations. Many of the public ditches were entirely on the tract and easily removed from local governmental jurisdiction. These were plugged and filled. In contrast, some of the ditches could not be entirely decommissioned and had to be either diked to restore adjacent wetlands or reconstructed to a more natural configuration while assuring adequate conveyance of runoff.

Early in the restoration process, the prior experience and desire of engineers with our major federal partner, the U.S. Department of Agriculture Natural Resources Conservation Service (NRCS), was to use large, elevated impoundments to create open-water marshes, which would be more conducive to waterbird nesting and stopover. This engineering approach diverged from TNC's interest in restoring shallow, ephemeral wetlands and wet meadows that matched the original conditions as much as possible. The two divergent restoration philosophies created contention early in the project when TNC noted that developing vegetation reflected marsh rather than wet meadow conditions [28]. TNC and NRCS worked for months to reconcile their differences and developed a compromise. They agreed that in most cases, little to no engineering was needed to restore wetlands because ditch fills and clay plugs would result in a natural return of a shallow water table. In some instances, where downstream flooding was a concern, designs consisted mainly of permanent broad-crested weirs, keyed laterally into swale margins, and used along existing infrastructure such as roads and the rail line that separates the north and south portions of the tract. Based on NRCS engineering plans, 1,240 ha of wetlands were restored by the end of the project.

During the restoration, $177 \mathrm{~km}$ of ditches were either filled or retrofitted, including $45 \mathrm{~km}$ of jurisdictional ditch (Figure 3a). TNC and NRCS records show that 1242 ha of wetlands were restored (Figure $3 b$ ). Although assessment of the restoration effects on the overall local hydrological budget is ongoing, initial modeling revealed that both groundwater recharge and surface-water runoff decreased at Glacial Ridge over the last decade, suggesting increased storage and evapotranspiration [29,30]. Perennial cover, fields no longer lying fallow, enhanced interception, development of grass tussocks and increased near-surface organic matter appear to mitigate rapid runoff and reduce infiltration. For example, although rainfall and snowmelt have not changed significantly during the last decade, records from the U.S. Geological Survey stream gauge on Judicial Ditch 66 suggest a notable decrease in flood peaks (Figure 4). A longer record will be required to establish the significance of this apparent trend. Furthermore, we anticipate improvements in water quality, which are currently being assessed by the U.S. Geological Survey. 
Figure 3. Restoration features at Glacial Ridge: (a) ditches filled (brown), reconfigured (violet), and unaltered (blue) (wide lines indicate reaches requiring county approval); (b) reconstructed or restored wetlands (green); (c) sequence of Wetland Reserve Program (WRP) contracts 1-9; (d) yearly progression of restoration and seeding ("Not Seeded" areas were existing grassland, active sand and gravel leases, or otherwise developed and not restored).
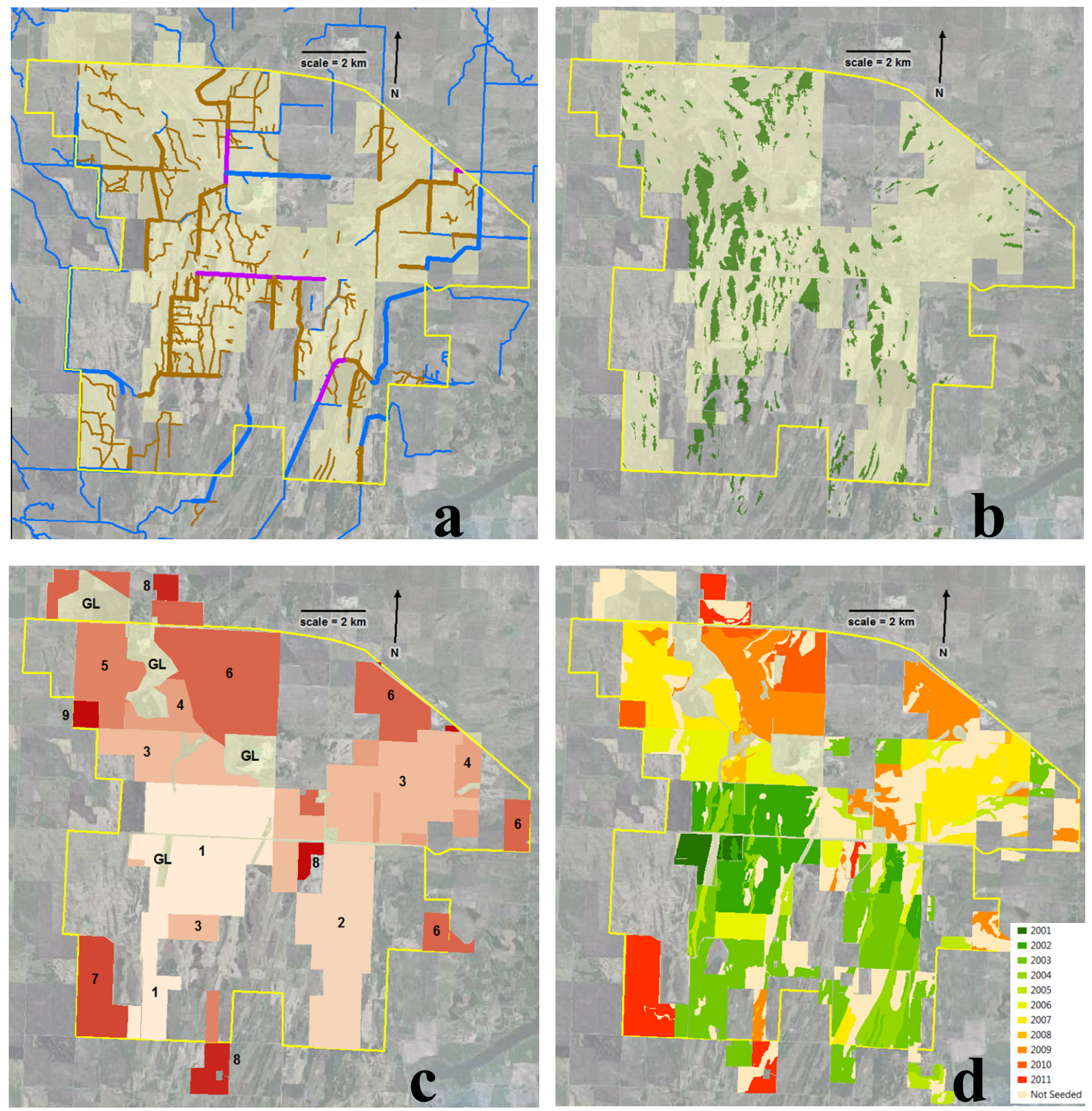
Figure 4. Hydrograph from U.S. Geological Survey gauging station \#05078770 on Judicial Ditch 66, which drains the northern part of the Glacial Ridge Project, plotted together with daily precipitation recorded at the National Weather Service station in Crookston, MN, USA (approximately $25 \mathrm{~km}$ northwest). Note the consistency of precipitation during the decade, but possible lower peak flow since 2006; restoration in the upper part of the watershed began with seeding several hundred ha in 2002.

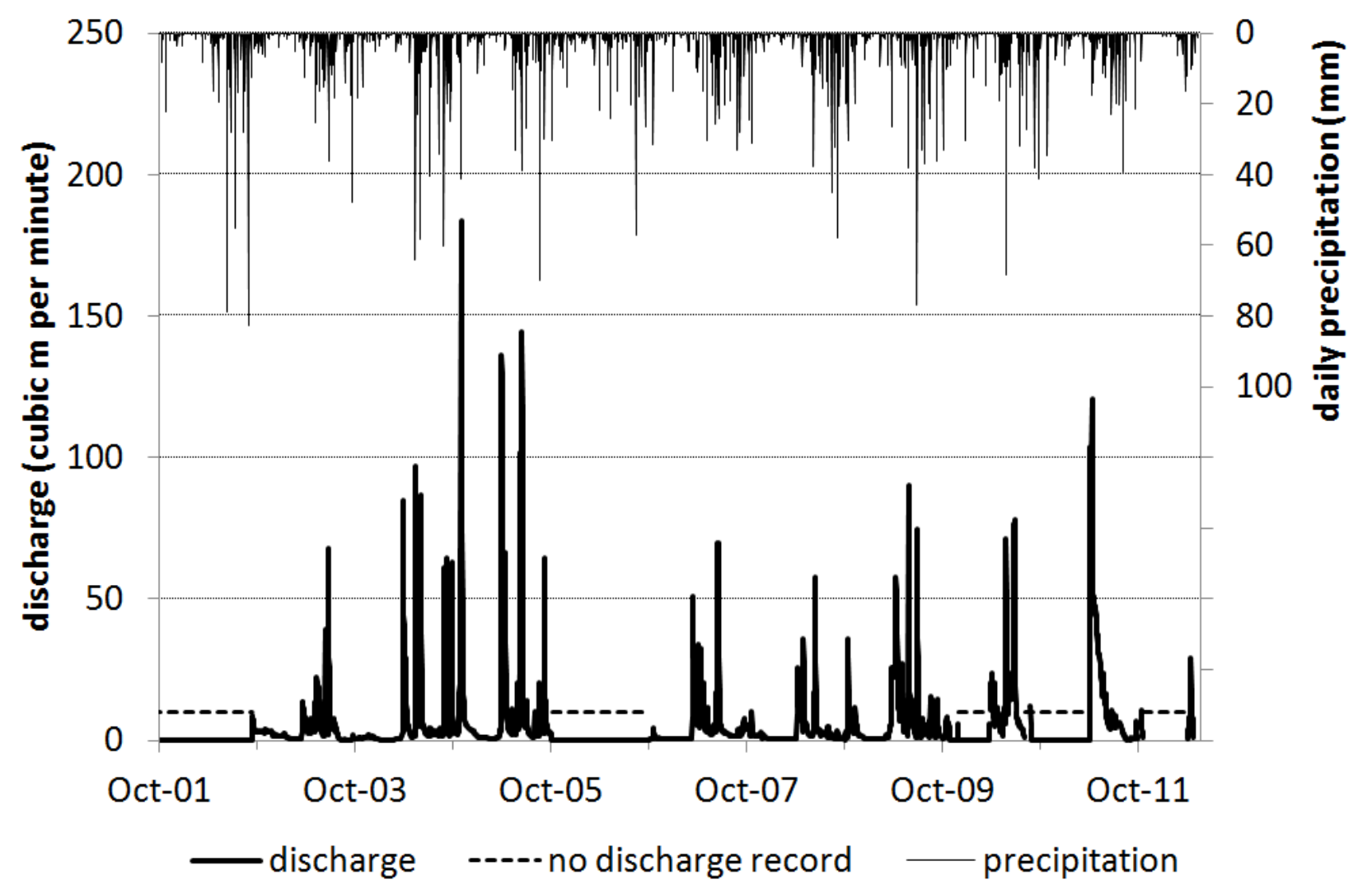

\subsection{Vegetation}

The proximity of the Glacial Ridge Project to several native prairie and wetland remnants was a significant advantage; these tracts proved indispensable as local seed sources. Large quantities of seed were harvested by combine on the remnants. Most harvested areas are owned by TNC (55\%) and the Minnesota Department of Natural Resources (40\%). The remainder of the seed was obtained from prairies under private ownership (5\%).

Multiple private laboratories conducted composition and seed viability analyses for each seed lot. Germination tests were conducted for every species constituting at least $5 \%$ of the mix; seed of other species was tested for viability using a tetrazolium assay. Seeds of noxious weeds such as thistle (Cirsium spp.) and leafy spurge (Euphorbia esula) were consistently absent from all seed lots. Seeds of undesirable species such as quack grass (Agropyron repens) and cool-season grasses such as smooth brome (Bromus inermis) and bluegrass (e.g. Poa pratensis) were common in some samples, but generally in low numbers because these weed seeds had usually fallen by the time of harvest. Knowledge of the vendors and their seed collection sites was critical to our ability to trust the validity of their seed tests. 
Generally, for every hectare of seed harvested, 2 ha could be planted. The quantity and viability of seed harvested, however, varied greatly. For example, a large crop might provide sufficient seed from 1 ha to plant as many as 6 ha. Conversely, in one year the seed crop was so sparse that as little as $1 / 4$ ha could be planted per 1 ha harvested. More than 500,000 kg of seed was harvested over the years to restore prairie vegetation at Glacial Ridge.

Initial seed collection emphasized the driest sites because local native seed from unplowed dry sites was the most limiting. Seed was harvested from native xeric, mesic, and hydric sites separately to assure the best seed for the landscape position in the project area. One of the challenges was obtaining sufficient seed for species that were missing from the combine-harvested mix. Combining took place in the fall, so some spring-flowering forbs and grasses were absent from the mix. In addition, short-statured species were missed by the combine. As a benefit to the project and local economy, entrepreneurial neighbors hand-collected seed from nearly 250 different native species, all of which was sold to the Glacial Ridge Project. In an average year replanting 1000 ha required roughly 13,000 kg of seed, approximately $5 \%$ (640 kg) of which was hand collected.

Canada thistle (Cirsium arvense), sweet clover (Melitotus sp.), birdsfoot trefoil (Lotus corniculatus), reed canarygrass (Phalaris arundinacea), and hybrid cattail (Typha x glauca) are among the most aggressive and invasive plants in the region. Additionally, smooth brome and non-native bluegrass (Poa sp.) are cool-season grasses that tend to be robust, dominant, and competitive compared to native warm-season grasses. Because the entire project area was not seeded at once, TNC leased the crop land to local corn and soybean farmers prior to reseeding the site. To help mitigate weeds and minimize the amount of crop matter left prior to replanting with native perennial species, TNC asked farmers to end in a rotation of glyphosate-resistant soybeans for the final growing season. Using row crops, particularly a corn and soy rotation, as a site preparation technique today is considered a best practice for prairie restoration [31].

Early in the project, seeds were drilled pneumatically, but it was expensive and time consuming, resulting in approximately 32 ha planted per day. By using dormant season broadcasting, we more than doubled planting rates to 81 ha per day. Dormant season broadcasting is considered a best practice for prairie restoration in Minnesota [32].

The NRCS required $8.7 \mathrm{~kg}$ of pure live seed (pls) per drilled ha on their restorations, and $13.1 \mathrm{~kg}$ $\mathrm{pls} /$ ha for broadcasting. This seeding rate corresponds to more than $480 \mathrm{seeds} / \mathrm{m}^{2}$. These requirements are based on seed mixtures of only 1 or 2 species of relatively large-seeded species such as big bluestem (Andropogon gerardi) and Indian grass (Sorghastrum nutans). TNC used diverse mixtures of native seed, including species with very small seeds. Although we could have lowered costs had NRCS adjusted their seeding rules, the heavy seeding rate likely contributed to the robust and diverse revegetation that occurred in many restoration tracts.

Specific ten-year restoration objectives for vegetation at Glacial Ridge included: (1) All restorations will contain at least $25 \%$ of possible native plant species characteristic of the target community; and (2) At least 75\% cover in all restorations will be native vegetation [33]. In 2007, vegetation across roughly 1150 ha was assessed using timed searches (6 hours per 65.75 ha block). Four years after planting, $60 \%$ of blocks met or exceeded the $25 \%$ threshold for characteristic native plant species. More than $70 \%$ of blocks surveyed met or exceeded the $75 \%$ cover target for native vegetation [34]. 
Aggressive post-restoration management was necessary to mitigate invasive weeds, which were a major concern of local residents. Generally, weeds were controlled by a high mowing of newly planted restorations once or twice a year after weed seed had set but before it fully matured. Mowing was subcontracted to local farmers. Additionally, restored prairies were burned within two or three years after planting, with many areas burned more than once during the first decade.

In 2008, vegetation was surveyed for a second set of restorations across a range of ages and soil conditions [35]. Using methods comparable to those developed in 2007, 803 ha were assessed. In addition, the effect of post-restoration management, including mowing and prescribed fire, was evaluated. Brand [35] reported higher percent cover of native species and greater richness of native graminoids and forbs for blocks with higher frequencies of prescribed fire and mowing. Approximately \$2.5 million was invested in post-restoration management over the course of the project, ineligible expenses under the NRCS's Wetland Reserve Program (WRP).

\section{Partnerships and Public Perception}

Partnership development was crucial to the ultimate success of this project both in terms of public perception and financial support. Partner involvement was critical at the local and county government level as well as at the federal level with our major partners, the NRCS and the U.S. Fish and Wildlife Service (USFWS). Other government agencies and academic institutions were important for measuring the success of the project along the way.

The NRCS, through their administration of the federal WRP, and the USFWS as the future manager of the tract as a National Wildlife Refuge (NWR), played key roles in the partnership that guided the restoration. The WRP helped to fund a large portion of the restoration costs, and the USFWS agreed to assume protection and responsibility for Glacial Ridge after completion of the restoration process. Complete restoration of Glacial Ridge was originally planned to have taken five years, with the intent for the USFWS to purchase parcels quickly, but a series of delays doubled the time to 10 years. It was not until 2004, a major federal election year, during which the refuge was created. At that time, TNC donated 930 ha, which became the initial acquisition for the Glacial Ridge NWR. Having management staff at the nearby Rydell NWR was critical because no budget funds were available for the new refuge until the size reached 4000 ha. Unfortunately, even at 7285 ha in mid-2011, the USFWS still had no formal budget for Glacial Ridge and continued to manage the project through the nearby Rydell NWR office.

Early in the restoration, many conservationists and scientists recognized the importance of monitoring the changes to the natural environment as the restoration proceeded. One of the earliest efforts was to involve the U.S. Geological Survey in collecting comprehensive baseline data on water balance and water quality within and surrounding the project area [36]. Conservation funds, primarily from state sources and matched by federal dollars, were received as grants and used to fund the hydrological assessment. A follow-up to this work is currently underway.

Complementing and expanding on research carried out by federal agencies, several regional colleges and universities involved students in conducting ecological studies at Glacial Ridge. Between 2006 and 2011, five master's theses resulted from work in site including restoration topics such as vegetation recovery [28,35], amphibian reproduction [37], and water quality [38,39]. In addition, 
peer-reviewed articles have documented aspects of the water budget [29,30,40-42], invasive species [26,43], restoration techniques [31], and partnerships [44] at Glacial Ridge. These publications set the stage for future work and long-term investigation.

As evidence of the successful development of the partnership and positive local perceptions, at least 70 local and regional newspapers articles and editorials have been published since the beginning of the project in 2000. The strong partnership, opportunities for outdoor recreation, and water quality were the most common topics and themes. All reflected favorably on the restoration effort, except for one that cited several negative national issues related to TNC.

Initial public perception of a project as large as Glacial Ridge, if not handled carefully, can potentially become negative and stall the work. TNC managers focused on quelling concerns about downstream flooding associated with ditch closures, paying taxes prior to and following the sale of the property to the USFWS, and offering optimal source protection for the municipal water supply within the project boundary.

\subsection{Downstream Flooding}

A common public misperception is that ditches mitigate floods regardless of their position in the watershed. Local residents pressured county commissioners to resist changing the status quo. In fact, at the time of the first ditch closure, the county required assistance from TNC's legal staff to understand the unprecedented decommissioning and judicial release of ditch authority from county government. TNC worked closely with the county board to authorize installation of clay plugs to restore natural hydrology. To build support, we started initially with only small reaches of isolated, headwater judicial ditches entirely within TNC ownership. As required by state law, we did so in the context of public meetings where we could provide accurate information about likely outcomes of ditch closures. Success in closing these less prominent public ditches provided the momentum and increased public trust to repeal local jurisdiction over larger, more significant drains.

\subsection{Property Taxes and Ownership}

As a registered non-profit organization, TNC is tax-exempt. A large project such as Glacial Ridge could have a significant reduction on local property tax revenue if taken off the tax rolls. Paying local and county property taxes, despite TNC's tax-exempt status, was essential to building local support for Glacial Ridge. To do so required creating a permanent endowment that would generate sufficient interest to pay local property taxes for the duration of TNC's ownership of the property. Agricultural income from lands leased in the first three years of the Glacial Ridge Project was used to build the corpus of the endowment.

Following the sale of the property to the USFWS, payment-in-lieu of-taxes took effect through the federal Refuge Revenue Sharing Program. This program pays a portion of local property taxes, but often falls short of full compensation. The permanent tax endowment originally established by TNC will make up the shortfall so that property taxes are paid perpetually in full at Glacial Ridge. Within two or three years, agricultural leases on the property generated sufficient funds to create an endowment to pay local and county property taxes in-perpetuity. 


\subsection{Municipal Water Supply}

The city of Crookston, Minnesota, with a population of about 9000, uses groundwater from aquifers that lie beneath the north end of Glacial Ridge. A significant proportion of the Minnesota Department of Health's 10-year well-head protection zone falls within the project area ("WHPA", Figure 1). About the time the project was initiated, the city was exploring ways to expand its source of drinking water. By allowing the city at no cost to expand to a new well site on the east (Figure 1), local perception of the Glacial Ridge project improved. Conversion of both well-head protection zones from intensive cultivation to natural perennial cover will help assure high-quality water for the city.

\section{Financing}

Although replicating the financial structure for Glacial Ridge in another landscape seems unlikely, the overall funding strategy provides a model that may be tailored to potential large-scale restorations in other regions.

The total project cost for Glacial Ridge was a little more than $\$ 27$ million. By the end of 2011, TNC recovered nearly all of its investment, and balanced income and payment on the project during the final sale of a small tract to the USFWS in early 2012. At Glacial Ridge, traditional non-profit charitable donations played a relatively minor role compared to income generated through four major sources: federal and state sources related to conservation payment programs, agricultural leases of crop land, rental income from an on-site, pre-existing agricultural seed cleaning and storage facility, and aggregate resource leases to private firms.

The two largest expenditures at Glacial Ridge were the purchase of land and the restoration work, with personnel, operations, and interest payments constituting most of the remaining expenses (Figure 5). Purchased for roughly $\$ 10$ million in the year 2000 as a highly-altered tract, it is worth noting that the land went on the market in the late 1970s, prior to conversion. The price tag at that time was approximately \$1 million, or around \$2.4 million when adjusted for inflation. In hindsight, the tract could have been purchased for roughly a tenth of the total project cost by investing in the native hydrology and vegetation.

Of the nearly \$8.2 million spent on direct restoration at Glacial Ridge (Figure 5), more than one-half went toward purchasing and harvesting native, local ecotype seed for high diversity plantings. Another $20 \%$ covered the costs of wetland restoration, including design, filling ditches, re-contouring basins, and other earthwork. A variety of post-restoration activities, such as weed management, constituted the remainder of the direct restoration expenses.

The Glacial Ridge funding strategy centered mainly on the NRCS WRP. WRP paid \$988/ha for upland restoration with a separate payment for the in-perpetuity easement on the property. TNC entered into nine sequential WRP contracts (Figure 3c). The scope of new contracts depended on prior contract progress and a prediction of seed and labor availability. The WRP process slowed over the course of the project. For example, in-the-field restoration was complete for WRP 7, 8, and 9 (Figure 3d) before the contracts were approved and signed. TNC decided to proceed with the work before funds were secured, although the WRP delay added significant short-term debt and posed a financial 
risk to TNC. WRP payments for permanent easements accounted for nearly $40 \%$ of the overall project budget (Figure 5). Further, WRP funds covered $77 \%$ of the total cost of restoration.

Figure 5. Major sources of income and expenses for the Glacial Ridge Project (percentage of totals over the 12-year restoration period).
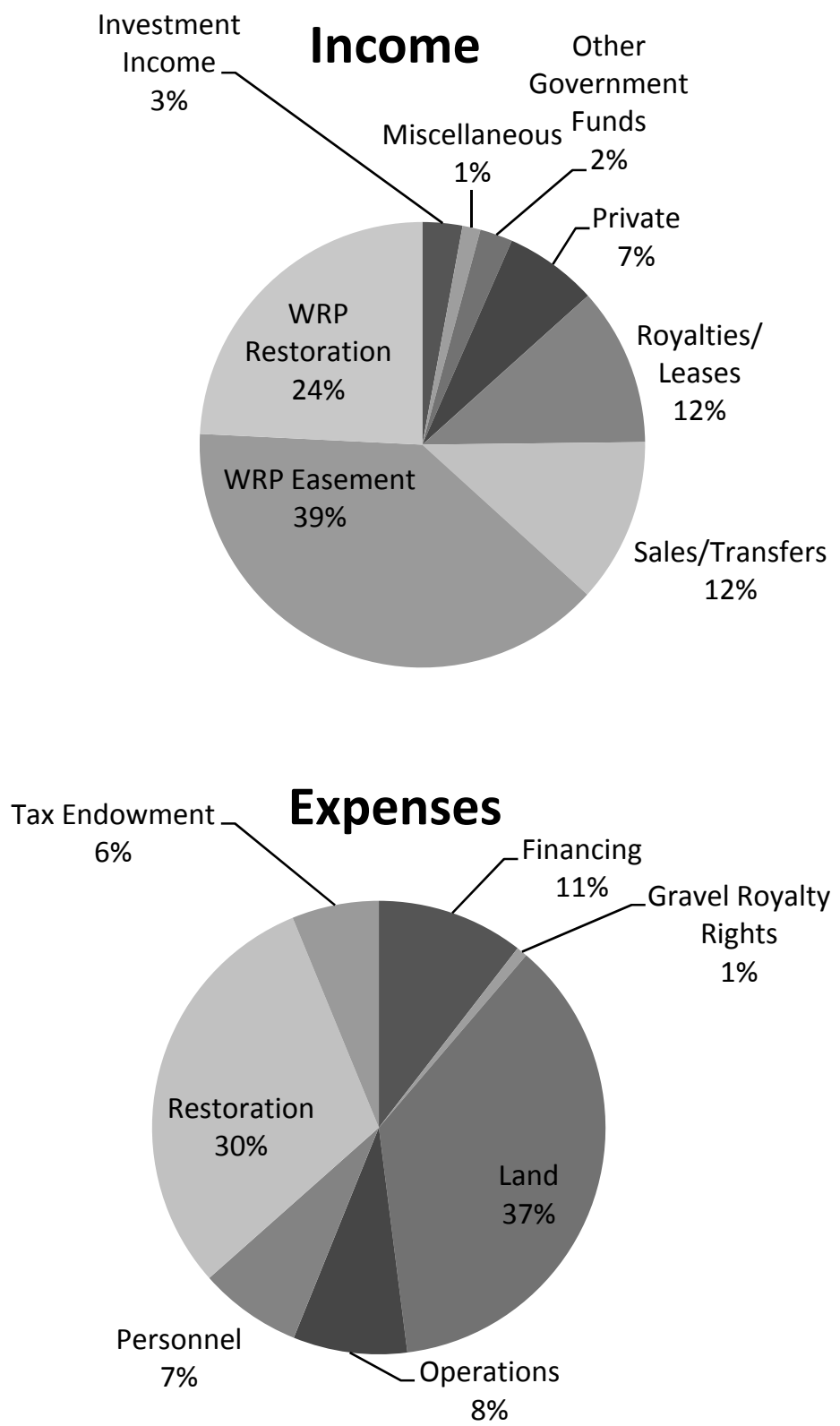

Other significant sources of funding included agricultural lease income, aggregate royalties, and sales and transfers of lands (Figure 5). When TNC started the restoration, 7690 ha of crop land was leased at approximately $\$ 111 /$ ha, generating more than $\$ 800,000$ per year. During the decade of restoration, lease rates rose to $\$ 185-\$ 272 / \mathrm{ha}$, and continue to rise, but the cost for high-diversity seed increased from $\$ 30$ in 2001 to $\$ 50-\$ 90$ per $\mathrm{kg}$ by 2011 , which more than offset the rise in lease payments. Compared to the large income from crop leases, grazing leases were much less profitable (\$25/ha), not counting a tax assessment of $\$ 15 /$ ha. The most productive agricultural lands were restored last. This tactic maximized the potential for crop land leases to defray project costs for the 
duration of the restoration. Leases for mining aggregate generated as much as $\$ 100,000$ per year and also generated tax income for the county.

\section{Keys to Success and Lessons Learned From Large-Scale Restoration}

Ultimately, the success of the Glacial Ridge reconstruction and restoration process depended on a few practical ingredients for success. Although replication of the approach and processes at Glacial Ridge are unlikely in most other areas, key lessons learned can be generalized to other landscapes. Specifically, we outline six factors for success and the related lessons learned (Table 2) from the Glacial Ridge experience that can be applied in any large-scale prairie wetland restoration.

Table 2. Lessons learned about large-scale restoration from the Glacial Ridge Project.

\begin{tabular}{cl}
\hline \multirow{2}{*}{ Financial } & $\begin{array}{l}\text { Fiscally and ecologically better to purchase prairies prior to plowing } \\
\text { Leasing portions of the land for income-generating activities such as agriculture or } \\
\text { mining can pay for the restoration process }\end{array}$ \\
\hline & $\begin{array}{l}\text { Gaining local public support for large-scale restorations early-on is essential } \\
\text { Clear, measurable restoration objectives should be established prior to beginning } \\
\text { restoration work }\end{array}$ \\
Restoration & $\begin{array}{l}\text { Larger projects mean more partners and a greater range of restoration goals, } \\
\text { objectives, and philosophies }\end{array}$ \\
& $\begin{array}{l}\text { Whenever possible, locate the project near native prairie remnants for better access } \\
\text { to local ecotype seed and maximum ecological benefits. }\end{array}$ \\
& Early resolution of partner differences lessens later problems and delays \\
\hline Measuring & $\begin{array}{l}\text { Engage local scientists from government or academic institutions to formulate } \\
\text { objectives and monitoring plans } \\
\text { Rapidly recovering ecological services should be measured and documented as soon } \\
\text { as possible } \\
\text { Early measures will help assure long-term support for post-project measures of } \\
\text { success }\end{array}$ \\
\hline
\end{tabular}

\subsection{Sufficiently Large Tract}

One of the primary keys to success for any large-scale restoration project is the availability of a large tract of restorable land under a single ownership, open for purchase when financial resources are accessible. Even more important, is the location of the tract within the landscape. The Glacial Ridge tract was perfectly situated to reconnect high diversity native prairie remnants. Such tracts are not common, which makes the Glacial Ridge situation serendipitous. Without the initially large parcel, a restoration project would need to be pieced together through the purchase of multiple smaller, contiguous parcels from different land owners, which would be much more challenging, time-consuming, and costly. The typical high price for large parcels is often a stumbling block for conservation organizations interested in purchasing land. This is the primary reason Glacial Ridge was not purchased in the late 1970s, prior to conversion to crop land. When making protection and investment decisions, however, organizations and agencies should also fully consider the potential cost for delaying purchase of the land, the cost of reconstructing the grasslands and wetlands, and the reality that a native system can never be fully restored to its original condition (Table 2). 


\subsection{Community and Partner Support}

The second critical factor for success is the support of local leaders and good public relations in the surrounding community. With large-scale restoration efforts, there is likely to be initial concern from local communities about removing land from the tax base and converting it to non-income-based land use. At Glacial Ridge, we purposely employed local professionals in the restoration efforts whose personalities and backgrounds would resonate with local political leaders and lead quickly to a trusting relationship. A strong and carefully managed public relations component was required to keep the project on track. We focused on benefits of the restoration to local sustainability, such as clean water, reduced flooding, jobs, and ecotourism. Additionally, the early income from the property was used to ensure that property taxes would be covered in-perpetuity. Over the course of the project, the restoration project contributed an average $\$ 1.4$ million per year to the local economy, provided $\$ 839,000$ per year in local labor income impact [19], and directly created 15 temporary jobs. For example, small businesses were initiated to provide local native seed to the project, and postseeding management was often contracted out to local landowners. All of these factors contributed to a favorable public perception of the project, and would help any project gain momentum.

Ostrom [45] recognized that common-pool resources (i.e., grasslands) can and are often governed successfully by common-property regimes, which contrast with state or private administration. Although privately owned by The Nature Conservancy during its development and restoration, Glacial Ridge was essentially managed in a common-property regime that included a range of stakeholders: federal conservation agencies, universities, county government, environmental organizations, and agricultural leases. Once the initial restoration was completed and turned over to the federal government, however, the tract no longer served as a common-pool resource.

To accomplish future large-scale restoration, we suggest that even larger tracts including both private and agency lands could be effectively self-managed by a local community (e.g., [46,47]). For example, a patchwork of native prairie, cropland, pasture, riparian areas, and wetlands could be integrated and managed to protect and enhance commodity production, biodiversity, water, soil quality, recreation, among others. Through owner pacts and easements, these composite tracts would be administered as common-property to optimize both production and ecological services, where stakeholders would provide long-term supervision.

\subsection{Nearby Prairie Remnants}

Situating large-scale restoration projects near scattered native prairie tracts may confer ecological benefits by reconnecting remnants. It also addresses the logistical issue of having a local ecotype seed source nearby, a critical enabling factor for large-scale restoration. Because large-scale restoration is most necessary in landscapes where conversion rates have been highest, the availability of native seed from local remnants may be a limiting factor for success. The remaining remnants in these types of landscapes are likely to be small, while the amount of seed needed for large-scale restorations is enormous. Glacial Ridge benefited from the proximity of relatively large, long-established native prairie preserves near or even adjacent to the property. The ecological consequences of harvesting seed 
from native prairies are largely unknown [48] and currently a focus of research by the University of Minnesota and TNC.

Similarly, field-scale experiments have shown that cultivated fields undergoing restoration can benefit greatly by inoculation with soil collected from established native prairie [49,50]. This technique first appeared in the literature at the time prairie restoration was nearly complete at Glacial Ridge, and therefore not attempted. However, because of the large volume of inoculant needed, collection of prairie soils could potentially damage existing small remnants and open areas to invasive weeds. For restoration tracts covering thousands of hectares, these techniques would likely need to be applied selectively in areas considered "difficult" to restore. Additionally, although increased soil nutrients after decades of cultivation likely enhanced conditions favorable to invasive species (e.g., [51,52]), this was not explicitly managed at Glacial Ridge and may be a factor important to restoration success.

\subsection{Secure Funding and Income}

The availability of funds to complete the restoration process is also a key factor in success. At Glacial Ridge, two main income streams were critical to paying for the restoration: leases (agriculture and aggregate mining) and WRP contracts. Large restoration projects in the future might be financed by simply coupling the restoration effort together with a strong on-the-ground income source such as lease income. Other projects could use this model to have regular income to pay for restoration activities, local taxes, and perpetual management. The agricultural leases may have been sufficient to pay for the restoration, particularly over a slightly longer timeframe, but the WRP contracts created a valuable partnership with the state and local NRCS. In the future, states' rights and fiscal austerity may greatly limit federal funding. Depending on how the political trends carry the public's view on government involvement in conservation, non-federal funding may be required for future large-scale projects. Our experience suggests that with careful planning funding similar projects with staggered agricultural lease or other income may be feasible.

\subsection{Effective Restoration Plan}

Many of the early communication issues with NRCS could have been avoided had a clear restoration plan with measureable conservation objectives been in place at the outset. By clearly establishing desired future conditions, such as preferred wetland restoration outcomes, the partners could have better navigated the conflict and tension in the early years of the project. In reality, a detailed restoration master plan was finalized four years into the project [33]. Any restoration project, particularly one as complex as Glacial Ridge, should clearly establish goals, methods, and partner roles prior to beginning the work on the ground.

Notwithstanding the critical importance of clear restoration objectives, flexibility and adaptability in the techniques used for restoration was crucial to the completion of the Glacial Ridge Project. The strategy for re-vegetating the site was worked out mostly by trial and error. Variability in some of the key resources necessary for restoration, such as native seed availability, required staff and plans to be adaptable. Additionally, drilling techniques that were successful elsewhere were not as effective in this landscape, an outcome consistent with Larson et al.'s [32] comparison of broadcasting, drilling, 
and season across sites from east-central Iowa to northwestern Minnesota. Rigid prescription of methods, although perhaps valuable and necessary for establishing funding and getting a project started, will likely need to be modified to guarantee success.

\subsection{Measures of Success}

To document success, measures need to be established at the beginning of the project in conjunction with the restoration objectives, assessed along the way, and evaluated at the end (Table 2). Some monitoring efforts should be focused on conditions and processes that will be affected quickly; continued funding and support often depend on demonstrating immediate improvements in the system. Our success in developing experiments and collecting data may have been more thorough if planning for scientific investigation and monitoring were advanced earlier in the restoration effort.

In their commentary on creating a framework to address the increasing urgency for large-scale restoration, Hobbs and Norton [8] state that "tackling this problem requires the development of guiding principles for restoration so that we can move away from the ad hoc, site- and situation-specific approach that now prevails." Large restoration projects such as Glacial Ridge can contribute greatly to scientific knowledge of prairie and wetland restoration specifically, and ecological dynamics in general. This foundation will facilitate successful grassland restoration at a scale necessary to retain tallgrass ecosystem sustainability, capture ecological heterogeneity, and begin to reverse the trend of decreasing grassland extent worldwide.

\section{Conclusions}

At the large scale that is going to be required to promote sustainability for some ecosystems, such as tallgrass prairie, the challenges are daunting but surmountable. The Glacial Ridge project provided insights for future large-scale restoration projects. Although we present several challenges and lessons learned, three key issues emerged as critical to the restoration success. The first is the availability of a large tract of land for purchase that can potentially provide connectivity to existing protected areas; without this, the rest of the process is impossible. The second is building local community support for the project. While parts of the restoration process may be possible without this support, the effort will be much more difficult and probably experience less long-term success. Finally, availability of local eco-type seed is a critical component and can be a limiting factor in many places where loss of prairie has been so severe that there may not be enough sources in the landscape to support large-scale restoration efforts. Similarly, methods and techniques that are well-adapted to restoring small sites may not work well at larger scales or across the landscape. Therefore, future field-scale and small site-specific experiments should be designed to inform and support long-term and large-scale restoration efforts.

\section{Acknowledgments}

Funding for this work was provided in part by The Nature Conservancy's Cox Family Fund for Science and Research. Additional funding was generously provided by the Plains and Prairie Potholes Landscape Conservation Cooperative (LCC) of the U.S. Fish and Wildlife Service. Cliff Huff provided 
detailed financial records that facilitated a summary of project expenses and income. Keith Mykleseth provided access to copies of more than 70 media stories about Glacial Ridge over its twelve-year history. Ron Nargang shared his perspective on the early days of the Glacial Ridge partnership. Many others from different agencies and organizations contributed to the success of the Glacial Ridge Project. John Shuey and four anonymous reviewers provided valuable suggestions on the content and organization of the manuscript.

\section{Conflict of Interest}

The authors declare no conflict of interest.

\section{References}

1. Hoekstra, J.M.; Boucher, T.M.; Ricketts, T.H.; Roberts, C. Confronting a biome crisis: Global disparities of habitat loss and protection. Ecol. Lett. 2005, 8, 23.

2. Stephens, S.E.; Walker, J.A.; Blunck, D.R.; Jayaraman, A.; Naugle, D.E.; Ringelman, J.K.; Smith, A.J. Predicting risk of habitat conversion in native temperate grasslands. Conserv. Biol. 2008, 22, 1320-1330.

3. Glover, J.D.; Culman, S.W.; DuPont, S.T.; Broussard, W.; Young, L.; Mangan, M.E.; Mai, J.G.; Crews, T.E.; DeHaan, L.R.; Buckley, D.H.; Ferris, H.; Turner, R.E.; Reynolds, H.L.; Wyse, D.L. Harvested perennial grasslands provide ecological benchmarks for agricultural sustainability. Agr. Ecosystems Environ. 2010, 137, 3-12.

4. DeLuca, T.H.; Zabinski, C.A. Prairie ecosystems and the carbon problem. Front. Ecol. Environ. 2011, 9, 407-413.

5. DuPont, S.T.; Culman, S.W.; Ferris, H.; Buckley, D.H.; Glover, J.D. No-tillage conversion of harvested perennial grassland to annual cropland reduces root biomass, decreases active carbon stocks, and impacts soil biota. Agr. Ecosystems Environ. 2010, 137, 25-32.

6. Samson, F.B.; Knopf, F.L.; Ostlie, W.R. Great Plains ecosystems: Past, present, and future. Wildlife Soc. B. 2004, 32, 6-15.

7. Koper, N.; Mozel, K.E.; Henderson, D.C. Recent declines in northern tall-grass prairies and effects of patch structure on community persistence. Biol. Conserv. 2010, 143, 220-229.

8. Hobbs, R.J.; Norton, D.A. Towards a conceptual framework for restoration ecology (1996). Restor. Ecol. 1996, 4, 93-110.

9. Merritt, D.J.; Dixon, K.W. Restoration seed banks-A matter of scale. Science 2011, 332, 424-425.

10. SER International Science \& Policy Working Group. The SER International Primer on Ecological Restoration; Society for Ecological Restoration International: Washington, DC, USA, 2004. Available online: http://www.ser.org/resources/resources-detail-view/ser-internationalprimer-on-ecological-restoration (accessed on 9 November 2012).

11. Bakker, J.P.; Berendse, F. Constraints in the restoration of ecological diversity in grassland and heathland communities. Trends Ecol. Evol. 1999, 14, 63-68.

12. Doyle, M.A. The Watershed-Wide, Science-Based Approach to Ecosystem Restoration. In Large-Scale Ecosystem Restoration: Five Case Studies from the United States; Doyle, M.A., Drew, C.A., Eds.; Island Press: Washington, DC, USA, 2008; pp. x-xiv. 
13. Davenport, M.A.; Bridges, C.A.; Mangun, J.C.; Carver, A.D.; Williard, K.W.J.; Jones, E.O. Building local community commitment to wetlands restoration: A case study of the Cache River wetlands in southern Illinois, USA. Environ. Manage. 2010, 45, 711-722.

14. McKay, J.K.; Christian, C.E.; Harrison, S.; Rice, K.J. "How local is local?"-A review of practical and conceptual issues in the genetics of restoration. Restor. Ecol. 2005, 13, 432-440.

15. Hedberg, P.; Kotowski, W. New nature by sowing? The current state of species introduction in grassland restoration, and the road ahead. J. Nat. Conserv. 2010, 18, 304-308.

16. Kiehl, K.; Kirmer, A.; Donath, T.W.; Rasran, L.; Hölzel, N. Species introduction in restoration projects-Evaluation of different techniques for the establishment of semi-natural grasslands in central and northwestern Europe. Basic Appl. Ecol. 2010, 11, 285-299.

17. Török, P.; Vida, E.; Deák, B.; Lengyel, S.; Tóthmérész, B. Grassland restoration on former croplands in Europe: An assessment of applicability of techniques and costs. Biodivers. Conserv. 2011, 20, 2311-2332.

18. Gascoigne, W.R.; Hoag, D.; Koontz, L.; Tangen, B.A.; Shaffer, T.L.; Gleason, R.A. Valuing ecosystem and economic services across land-use scenarios in the Prairie Pothole Region of the Dakotas, USA. Ecol. Econ. 2011, 70, 1715-1725.

19. U.S. Department of the Interior. The Department of the Interior's Economic Contributions, FY 2011; U.S. Department of the Interior: Washington, DC, USA, 2012; Chapter 4, Ecosystem Restoration, pp. 58-92.

20. Omernik, J.M.; Gallant, A.L. Ecoregions of the Upper Midwest States; EPA/600/3-88/037; U.S. Environmental Protection Agency: Corvallis, OR, USA, 1988.

21. Teller, J.T.; Clayton, L. Glacial Lake Agassiz; Geological Association of Canada Special Paper 26; Geological Association of Canada: St. John's, Newfoundland, Canada, 1983.

22. Anderson, R.C. Evolution and origin of the central grassland of North America: Climate, fire, and mammalian grazers. J. Torrey Bot. Soc. 2006, 133, 626-647.

23. Anderson, R.C. The Historic Role of Fire in the North American Grassland. In Fire in North American Tallgrass Prairies; Collins, S.L., Wallace, L.L., Eds.; University of Oklahoma Press: Norman, OK, USA, 1990; pp. 8-18.

24. Steinauer, E.M.; Collins, S.L. Prairie Ecology—The Tallgrass Prairie. In Prairie Conservation; Samson, F.B., Knopf, F.L., Eds.; Island Press: Washington, DC, USA, 1996; pp. 39-52.

25. Engle, D.M.; Bidwell, T.G. Viewpoint: The response of central North American prairies to seasonal fire. J. Range Manage. 2001, 54, 2-10.

26. Rowe, H.I.; Fargione, J.; Holland, J.D. Prairie restorations can protect remnant tallgrass prairie plant communities. Am. Midl. Nat. 2012, in review.

27. NatureServe. NatureServe Explorer-An Online Encyclopedia of Life. Available online: http://www.natureserve.org/explorer/ (accessed on 9 November 2012).

28. Janke, T.P. Floral species richness of restored wetlands of the Glacial Ridge National Wildlife Refuge: Examining the utility of species pools in restoration monitoring. Master's Thesis, University of North Dakota, Grand Forks, ND, USA, 2006.

29. Gerla, P.J. Estimating the effect of cropland to prairie conversion on peak storm runoff. Restor. Ecol. 2007, 15, 720-730. 
30. Gerla, P.J. Field-scale changes in soil water and recharge following restoration of a cultivated field to prairie. J. Environ. Hydrol. 2011, 19, 1-13.

31. Rowe, H.I. Tricks of the trade: Techniques and opinions from thirty-eight experts in tallgrass prairie restoration. Restor. Ecol. 2010, 18, 253-262.

32. Larson, D.L.; Bright, J.B.; Drobney, P.; Larson, J.L.; Palaia, N.; Rabie, P.A.; Vacek, S.; Wells, D. Effects of planting method and seed mix richness on the early stages of tallgrass prairie restoration. Biol. Conserv. 2011, 144, 3127-3139.

33. Brown, J.; Cornett, M.; Ekstein, J.; Gerla, P.; Wahl, S. Master Plan for Restoration, Management, and Monitoring at Glacial Ridge; The Nature Conservancy: Minneapolis, MN, USA, 2005.

34. Cornett, M.; Nixon, B.; Arikian, M. The Nature Conservancy, Minneapolis, MN, USA, unpublished data.

35. Brand, G.L. Development of a Rapid Monitoring Approach to Inform Management Decisions on a Large Tallgrass Prairie undergoing Restoration. M.S. Thesis, University of Minnesota, Minneapolis, MN, USA, 2011.

36. Cowdery, T.K.; Lorenz, D.; Arntson, A. Hydrology Prior to Wetland and Prairie Restoration in and around the Glacial Ridge National Wildlife Refuge, Northwestern Minnesota, 2002-2005; U.S. Geological Survey Scientific Investigations Report 2007-5200, U.S. Government Printing Office: Washington, DC, USA, 2008.

37. Larson, J.A. Amphibian Reproduction in Restored Wetland Habitat in Northwestern Minnesota. M.S. Thesis, University of North Dakota, Grand Forks, ND, USA, 2007.

38. Whittaker, R.J. Predicting the Effect of Wetland Restoration on Phosphorous Retention, Northwest Minnesota. M.S. Thesis, University of North Dakota, Grand Forks, ND, USA, 2009.

39. Suggs, R.A. Using Temperature Profiles to Investigate the Hyporheic Zone in an Agricultural Ditch. M.S. Thesis, University of North Dakota; Grand Forks, ND, USA, 2011.

40. Oberg, J.W.; Melesse, A.M. Evapotranspiration dynamics at an ecohydrological restoration site: An energy balance and remote sensing approach. J. Am. Water Resour. Assoc. 2006, 42, 565-582.

41. Melesse, A.M.; Oberg, J.; Nangia, V.; Beerie, O.; Baumgartner, D. Spatiotemporal dynamics of evapotranspiration at the Glacial Ridge prairie. Hydrolog. Process 2006, 20, 1451-1464.

42. Newman, A.J.; Kuchera, P.A.; Williams, C.R.; Bliven, L.F. Snowflake size spectra retrieved from a UHF vertical profiler. J. Atmos. Ocean. Tech. 2009, 26, 180-189.

43. Almquist, T.L.; Lym, R.G. Effect of aminopyralid on Canada thistle (Cirsium arvense) and the native plant community in a restored tallgrass prairie. Invasive Plant Sci. Manag. 2010, 3, 155-168.

44. Hayek, M. Glacial Ridge National Wildlife Refuge: A partnership from the beginning. Rangelands 2012, 34, 45-49.

45. Ostrom, E. Governing the Commons: The Evolution of Institutions for Collective Action; Cambridge University Press: Cambridge, UK, 1990; p. 298.

46. Ostrom, E. A general framework for analyzing sustainability of social-ecological systems. Science 2009, 325, 419-422.

47. Poteete, A.R.; Janssen, M.A.; Ostrom, E. Working Together: Collective Action, the Commons, and Multiple Methods in Practice; Princeton University Press: Princeton, NJ, USA, 2010; p. 370. 
48. Menges, E.S.; Guerrant, E.O.; Hamze, S. Effects of Seed Collection on the Extinction Risk of Perennial Plants. In Ex Situ Plant Conservation: Supporting Species Survival in the Wild; Guerrant, E.O., Havens, K., Maunders, M., Eds.; Island Press: Washington, DC, USA, 2004; pp. 304-324.

49. Fitzsimons, M.S.; Miller, R.M. The importance of soil microorganisms for maintaining diverse plant communities in tallgrass prairie. Am. J. Bot. 2010, 97, 1937-1943.

50. Middleton, E.L.; Bever, J.D. Inoculation with a native soil community advances succession in a grassland restoration. Restor. Ecol. 2012, 20, 218-226.

51. Maron, J.L.; Jefferies, R.L. Restoring enriched grasslands: Effects of mowing on species richness, productivity, and nitrogen retention. Ecol. Appl. 2001, 11, 1088-1100.

52. Corbin, J.D.; D’Antonio, C.M. Gone but not forgotten? Invasive plants' legacies on community and ecosystem properties. Invasive Plant Sci. Manage. 2012, 5, 117-124.

(C) 2012 by the authors; licensee MDPI, Basel, Switzerland. This article is an open access article distributed under the terms and conditions of the Creative Commons Attribution license (http://creativecommons.org/licenses/by/3.0/). 